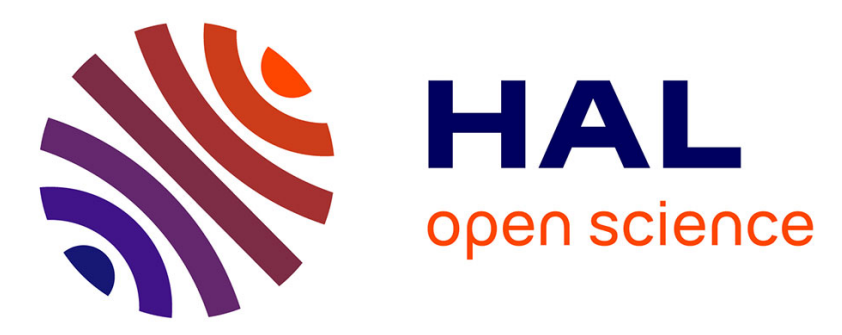

\title{
A neutralizing monoclonal antibody (mAb A24) directed against the transferrin receptor induces apoptosis of tumor T lymphocytes from ATL patients
}

Ivan C. Moura, Yves Lepelletier, Bertrand Arnulf, Ali Bazarbachi, Renato C. Monteiro, Olivier Hermine

\section{To cite this version:}

Ivan C. Moura, Yves Lepelletier, Bertrand Arnulf, Ali Bazarbachi, Renato C. Monteiro, et al.. A neutralizing monoclonal antibody (mAb A24) directed against the transferrin receptor induces apoptosis of tumor T lymphocytes from ATL patients. Blood, 2004, 103 (5), pp.1838 - 1845. 10.1182/blood2003-07-2440 . pasteur-03525664

\section{HAL Id: pasteur-03525664}

https://hal-pasteur.archives-ouvertes.fr/pasteur-03525664

Submitted on 14 Jan 2022

HAL is a multi-disciplinary open access archive for the deposit and dissemination of scientific research documents, whether they are published or not. The documents may come from teaching and research institutions in France or abroad, or from public or private research centers.
L'archive ouverte pluridisciplinaire HAL, est destinée au dépôt et à la diffusion de documents scientifiques de niveau recherche, publiés ou non, émanant des établissements d'enseignement et de recherche français ou étrangers, des laboratoires publics ou privés.

$$
\text { Copyright }
$$




\section{A neutralizing monoclonal antibody (mAb A24) directed against the transferrin receptor induces apoptosis of tumor T lymphocytes from ATL patients}

Ivan C. Moura, Yves Lepelletier, Bertrand Arnulf, Patrick England, Cedric Baude, Carole Beaumont, Ali Bazarbachi,

Marc Benhamou, Renato C. Monteiro, and Olivier Hermine

Adult T-cell leukemia/lymphoma (ATL) is an aggressive lymphoid proliferative disease that exists under diverse clinical forms ranging from chronic to acute. Although leukemic cells from patients with ATL exhibit an intrinsic resistance to chemotherapy, monoclonal antibodies directed against CD25 (interleukin 2 receptor $\alpha$ [IL-2R $\alpha]$ antibody) have been used as specific therapeutic agents. However, significant clinical results with these antibodies have been demonstrated only in chronic forms of ATL. In contrast to rest- ing $\mathrm{T}$ cells, human T-cell lymphotropic virus type 1 (HTLV-1)-infected cells constitutively express high levels of surface transferrin receptor (TfR). Herein, we report the characterization of a new monoclonal antibody (mAb A24) directed against the human TfR and the evaluation of its capacity to block the proliferation of ATL cells ex vivo. We determined that A24 binds TfR with an equilibrium constant $\left(\mathrm{K}_{\mathrm{d}}^{\prime}\right)$ of $2.7 \mathrm{nM}$ and competes with transferrin for binding to TfR. A24 also inhibited $\left[{ }^{55} \mathrm{Fe}\right]$-transferrin uptake in activated
T cells and blocked T-cell proliferation. Moreover, A24 reduced and impaired TfR expression and recycling, respectively. Most important, we showed that A24 blocked the ex vivo proliferation of malignant $T$ cells from both acute and chronic forms of ATL, through induction of programmed cell death. Therefore efficient therapeutic tools to treat acute forms of ATL might be derived from A24. (Blood. 2004; 103:1838-1845)

๑) 2004 by The American Society of Hematology

\section{Introduction}

Adult T-cell leukemia/lymphoma (ATL) is an aggressive lymphoproliferative disorder associated with the human T-cell lymphotropic virus type 1 (HTLV-1). ${ }^{1} \mathrm{HTLV}-1$ infection is endemic mainly in Japan and in the Caribbean, affecting 20 to 30 million individuals worldwide. HTLV-1 was the first human retrovirus in which monoclonal provirus integration in the host cellular DNA was observed. ATL occurs in only $2 \%$ to $4 \%$ of people infected with HTLV-1. The tumor syndrome comprises a proliferation of tumor $\mathrm{CD}^{+}{ }^{+} \mathrm{T}$ cells in peripheral blood, lytic bone lesions, and multiple visceral lesions with skin and lung infiltration. ${ }^{2}$ It exhibits diverse clinical features ranging from chronic to acute forms.

Smoldering and chronic forms exhibit a relatively good prognosis with an indefinite or 36-month median survival time, respectively. In these forms it is not yet demonstrated that treatment may improve prognosis and reduce the risk of evolution toward an acute form. In contrast, acute leukemic and lymphomatous forms of ATL have a very bad prognosis with a median survival of only 6 and 10 months, respectively, and a projected 4 -year survival of about $5 \%$. This is principally due to a severe immunodeficiency associated in some cases with opportunistic infections ${ }^{3}$ and to an intrinsic resistance to high doses of chemotherapy. Novel treatments, such as the association of interferon $\alpha(\mathrm{IFN}-\alpha)$ and zidovudine (AZT), produced a high response rate in ATL patients with minimal side effects and seemed to prolong survival.-7 Yet, only a small percentage of patients achieve long-lasting remissions.

HTLV-1-infected T cells overexpress markers of T-cell activation such as interleukin 2 receptor $\alpha(\mathrm{IL}-2 \mathrm{R} \alpha)$ when compared with uninfected stimulated $\mathrm{T}$ cells from the same donors. ${ }^{89}$ Immunotherapy, using unlabeled or radiolabeled humanized antibodies directed against $\mathrm{IL}-2 \mathrm{R} \alpha,{ }^{10,11}$ have exploited the difference in IL-2R $\alpha$ expression between normal and malignant cells. However, clinical trials have shown that $\mathrm{T}$ cells derived from patients with acute ATL were in most cases resistant to anti-IL-2R $\alpha$ treatment. ${ }^{10,12}$

The transferrin receptor (TfR) is another inducible receptor that is overexpressed in ATL cells, ${ }^{13}$ whereas its background level in resting cells is very low. TfR is a disulfide-linked homodimeric transmembrane glycoprotein consisting of two 760-amino acid monomers of approximately $90 \mathrm{kDa}$ each. TfR plays a crucial role in the regulation of iron uptake and cell growth. ${ }^{14,15}$ When diferric transferrin binds to its cell surface receptor, it is internalized via clathrin-coated pits to acidic vesicles where the iron-transferrin complex is dissociated. ${ }^{16,17}$ After release, the receptor and apotransferrin recycle back to the cell surface.

TfR is constitutively expressed in cells of tissues that are constantly renewed, such as precursors of blood cells in the bone marrow, hepatocytes in the liver, keratinocytes in the epidermis,
From the Institut National de la Santé et de la Recherche Médicale (INSERM) E-0225, Faculté de Médecine Xavier Bichat, Paris, France; Centre National de Recherche Scientifique (CNRS) FRE-2444, Hôpital Necker, Paris, France; Plateforme de Biophysique des Macromolécules et de leurs Interactions, Institut Pasteur, Paris, France; INSERM U-409, Faculté de Médecine Xavier Bichat, Paris, France; Departments of Internal Medicine and Biochemistry, American University of Beirut, Beirut, Lebanon; and Department of Clinical Hematology, Hôpital Necker, Paris, France

Submitted July 18, 2003; accepted October 16, 2003. Prepublished online as Blood First Edition Paper, October 30, 2003; DOI 10.1182/blood- 2003-07-2440.

Supported by grants from Arecca and la Ligue contre le Cancer. I.C.M. and Y.L. were both recipients of la Ligue contre le Cancer fellowship.

I.C.M. and Y.L. contributed equally to this work.

Reprints: Olivier Hermine, Hôpital Necker, 161 rue de Sèvres, 75743 Paris Cedex 15, France; e-mail: hermine@necker.fr; or Renato C. Monteiro, Faculté de Médecine Xavier Bichat, 16, rue Henri Huchard 75018 Paris Cedex 15, France; e-mail: monteiro@bichat.inserm.fr.

The publication costs of this article were defrayed in part by page charge payment. Therefore, and solely to indicate this fact, this article is hereby marked "advertisement" in accordance with 18 U.S.C. section 1734

(C) 2004 by The American Society of Hematology 
and enterocytes in crypts of intestinal epithelium. ${ }^{17-20}$ More importantly, several studies have shown that TfR is expressed more abundantly in malignant tissues than in their healthy counterparts. $^{20-22}$ Therefore, TfR could be a relevant target for new antibody-based therapies against tumors.

Several authors have reported therapeutic approaches based on this idea using anti-TfR antibodies or transferrin itself conjugated to drugs to kill malignant cells. ${ }^{23-25}$ It has been shown that neutralizing anti-TfR antibodies can block the interaction between transferrin and TfR, and consequently iron uptake, leading to iron deprivation and negative regulation of cell growth. In this work, we have investigated the level of expression of TfR in tumor cells from acute and chronic ATL forms and the in vitro impact of a new neutralizing anti-TfR monoclonal antibody (mAb), A24, ${ }^{26}$ on cell proliferation and survival. We show that TfR is expressed on ATL lymphocytes, both in acute and chronic ATL forms. More importantly, we demonstrate that A24 is efficient in promoting the death of malignant cells from chronic and acute forms of ATL through induction of apoptosis.

\section{Materials and methods}

\section{Reagents and antibodies}

IL-2 and phytohemagglutinin (PHA) were both from Roche Diagnostics (Meylan, France). Anti-CD25-fluorescein isothiocyanate (FITC), anti-CD3allophycocyanin (APC), anti-TfR-phycoerythrin (PE), irrelevant mouse IgG-FITC, mouse IgG-APC, and mouse IgG-PE isotype controls were all from Immunotech (Marseille, France). Chemotherapeutic agents were used at the following concentrations: zidovudine (AZT; Wellcome Research Labs, Beckenham, United Kingdom) at $0.2 \mu \mathrm{M}$, anti-IL-2R $\alpha \mathrm{mAb}$ (Hoffmann-La Roche, Nutley, NJ) at $10 \mu \mathrm{g} / \mathrm{mL}$, IFN- $\alpha$ (Hoffman-La Roche, Basel, Switzerland) at $100 \mathrm{U} / \mathrm{mL}$, and arsenic trioxide (Sigma Chemical, St Louis, MO) at $1 \mu \mathrm{M}$. The anti-human TfR (CD71) mAb A24 has been already described in detail ${ }^{26}$ and the isotype-matched $\mathrm{mAb} 30.9$ directed against the rat $\mathrm{Fc} \in \mathrm{RI}$ chain was used as a control. ${ }^{27}$ Protein concentrations were determined using the BCA kit as recommended by the manufacturer (Pierce, Rockford, IL).

\section{Isolation and culture of cells}

Peripheral blood mononuclear cells (PBMCs) were isolated as described ${ }^{28}$ earlier by the standard Ficoll-Paque method (Amersham Life Science, Buckinghamshire, United Kingdom). Healthy volunteers and 4 patients with acute ATL and 3 with chronic ATL (classified following Shirono criteria) ${ }^{29}$ had all given their informed consent. The study was approved by the ethics committee of Hôpital Pitié Salpetrière (Paris, France). ATL tumor cells represented between $60 \%$ and $90 \%$ of the T-cell population. Each cell type was freshly cultured in conditioned RPMI 1640 medium supplemented with $10 \%$ fetal calf serum (FCS; Gibco, Grand Island, NY) and a mixture of IL-2 (20 U/mL) and PHA (4 $\mu \mathrm{g} / \mathrm{mL})$. Mixed leukocyte reaction (MLR) was performed as described earlier. ${ }^{30} \mathrm{CIB}$ tropical spastic paraparesis (HAM/TSP) cell line was cultured in RPMI 1640 medium supplemented with $10 \%$ FCS.

\section{Flow cytometry}

For single-, double-, and 3-color flow cytometry, cells were incubated for 15 minutes at $4{ }^{\circ} \mathrm{C}$ in phosphate-buffered saline (PBS), $2 \% \mathrm{FCS}$, and $0.1 \%$ $\mathrm{NaN}_{3}$, with FITC-, APC- and PE-conjugated anti-CD25-, anti-CD3-, and anti-CD71-specific antibodies or with control isotype-matched irrelevant antibodies at the appropriate concentration (Immunotech, Marseille, France). After washing, $2 \times 10^{4}$ events were analyzed with a FACScan (Becton Dickinson, Heidelberg, Germany).

\section{Confocal microscopy}

CIB cells were plated on slides coated with poly-L-lysine (Sigma) and incubated for 30 minutes at $4^{\circ} \mathrm{C}$. Cells were then labeled with the mAb A24 at $10 \mu \mathrm{g} / \mathrm{mL}$ during 30 minutes at $4^{\circ} \mathrm{C}$. After 2 washes in PBS $/ 2 \%$ FCS, cells were plated in RPMI 1640 with $10 \% \mathrm{FCS}$ for various times at $37^{\circ} \mathrm{C}$ or kept on ice. Cells were then fixed in $1 \%$ paraformaldehyde, quenched with $0.1 \mathrm{M}$ glycine, and permeabilized with $1 \%$ saponin in PBS containing $1 \%$ bovine serum albumin Primary antibodies were revealed by a goat antimouse IgG conjugated to $\mathrm{Cy}-5$ (Jackson ImmunoResearch, West Grove, PA). After 2 additional washes in $\mathrm{PBS} / 2 \%$ FCS, cells were incubated for 5 minutes with $2 \mu \mathrm{g} / \mathrm{mL}$ wheat-germ agglutinin (WGA) conjugated to Alexa-488 to delineate the plasma membrane and washed again. Mounted slides were examined with a confocal laser microscope system (LSM 510; Carl Zeiss, Göttingen, Germany).

\section{Proliferation assay}

PBMCs were resuspended in RPMI 1640 with $10 \%$ FCS and added in triplicate at the concentration of $10^{5}$ cells/well in 96-well tissue culture plates (Falcon, Oxnard, CA). Proliferation was measured over 18 hours, using pulses with $1 \mu \mathrm{Ci} /$ well $\left(0.037 \mathrm{MBq} /\right.$ well) $\left[{ }^{3} \mathrm{H}\right]$-thymidine (Amersham Life Science). Cells were then harvested with a 96-well Harvester (Pharmacia, St Quentin, France) and collected on filters (Pharmacia); and the incorporation of $\left[{ }^{3} \mathrm{H}\right]$-thymidine was measured with $\beta$-plate microscintillation counter (LKB; Pharmacia).

\section{Assay for apoptosis}

Two million PBMCs from patients with HTLV-1 were treated for 96 hours with IL-2 and PHA in the presence or absence of A24 $(10 \mu \mathrm{g} / \mathrm{mL}), 30.9(10 \mu \mathrm{g} / \mathrm{mL})$, or the apoptosis-inducing agent VP16 $(100 \mathrm{ng} / \mathrm{mL})$. Cells were then washed with ice-cold PBS and incubated with a combination of annexin V-FITC and propidium iodide (PI; Beckman Coulter), according to the manufacturer's recommendations. Alternatively, the apoptosis was evaluated through mitochondrial membrane depolarization with DIOC ( $3,3^{\prime}$-dihexyloxacarbocyanine) staining (Molecular Probes, Eugene, OR) as described earlier. ${ }^{31}$

\section{$\left[{ }^{55} \mathrm{Fe}\right]-$ transferrin uptake studies}

Apo-transferrin was loaded with $\left[{ }^{55} \mathrm{Fe}\right]$ to $99 \%$ saturation as described. ${ }^{32}$ PBMCs cultured at $1 \times 10^{6} / \mathrm{mL}$ for 48 hours in PHA/IL-2-conditioned medium were exposed to $2.5 \mu \mathrm{M}\left[{ }^{55} \mathrm{Fe}\right]$-transferrin for the times indicated. At the end of the uptake time, cells were washed 4 times in PBS and lysed in $0.1 \%$ Triton X-100 in PBS. Radioactivity per gram protein in the lysates was counted in a $\beta$ counter.

\section{Surface plasmon resonance assays}

All the assays were performed on a BIAcore 2000 instrument equilibrated at $25^{\circ} \mathrm{C}$ with PBS plus $0.005 \%$ Tween-20 at a flow rate of $50 \mu \mathrm{L} / \mathrm{min}$. The Penta-His mAb (Qiagen, Hilden, Germany) was covalently immobilized on the carboxymethylated surface of a CM5 sensorchip, using the Amine Coupling Kit (BIAcore, Paris, France). Production and purification of soluble TfR was previously described. ${ }^{33}$ Recombinant (His) - $_{6}$ tagged TfR1 ectodomain (TfR(His) $)_{6}$ ) was captured to a level of 120 resonance units (RU; low density) or 1650 RU (high density) on the anti-(His) $)_{6}$ surface. Ten different concentrations of mAb A24 (1-500 nM) or of Fe-transferrin (0.25-150 nM) were then injected across the anti-(His) $)_{6} / \mathrm{TfR}$-(His) 6 surface for 4 minutes, and the dissociation of the complexes was followed for 5 minutes. Control experiments were performed by injecting A24 or Fe-transferrin directly onto the anti-(His) ${ }_{6}$ surface. The association and dissociation profiles were analyzed with a nonlinear least squares algorithm implemented in the BIAevaluation 3.0 software (BIAcore), using single-exponential functions of time. For the competition experiments, saturating A24 or Fe-transferrin ( $300 \mathrm{nM}$ ) was injected onto the low-density anti-(His) 6 /TfR(His) 6 surface, followed 1 minute later by, respectively, Fe-transferrin or A24 (15 $\mathrm{nM}$ ). The resulting association profiles were compared with those obtained without the preliminary saturation step (control injection of buffer).

\section{Results}

A24 inhibits the proliferation of activated T cells

Previously, A24 was characterized as a mAb directed against TfR. ${ }^{26}$ Because TfR expression is required for T-cell growth, we tested 


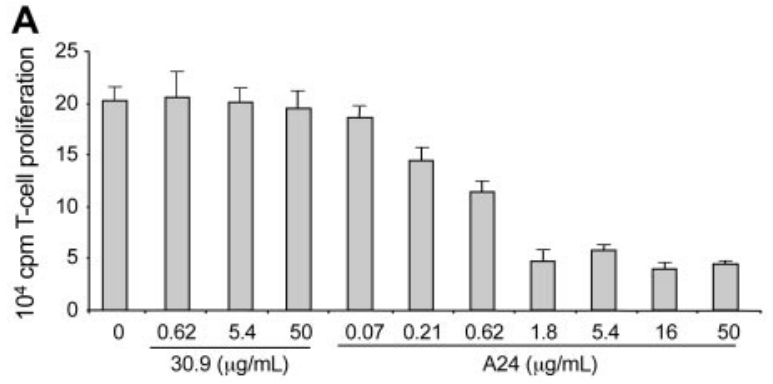

whether TfR targeting by A24 could inhibit cell proliferation. Thus, PBMCs were activated for 72 hours with PHA/IL-2 in the presence of different concentrations of A24 or the isotype-matched control 30.9. A24 efficiently reduced cell proliferation (50\% inhibitory concentration $\left[\mathrm{IC}_{50}\right] 0.5 \mu \mathrm{g} / \mathrm{mL}$ or $3 \mathrm{nM}$, Figure $\left.1 \mathrm{~A}\right)$. In contrast, 30.9 did not interfere with PHA/IL-2-induced cell proliferation. To test if A24 could also block physiologically activated T-cell proliferation, we examined the effect of A24 in allogeneic MLRs. Coculture of dendritic cells, activated by tumor necrosis factor $\alpha$ (TNF- $\alpha$ ) and IL-1 $\beta$, with resting T cells induced T-cell proliferation. On addition of A24 to the cocultured cells, a strong inhibition of T-cell proliferation was observed ( $>90 \%$; Figure 1B). Arsenic trioxide (Ars; a compound that was previously shown to induce apoptosis of activated $\mathrm{T}$ cells) was also shown to block T-cell proliferation. $^{28}$

\section{ATL cells express TfR, and A24 inhibits the proliferation of cells from chronic and acute forms of ATL and the emergence of HTLV-1-infected T-cell clones}

It was previously shown that the in vitro infection of $\mathrm{T}$ cells with HTLV-1 induces the up-regulation of TfR on the cell surface. ${ }^{34}$ Figure 2A shows the differential expression of TfR in freshly isolated and in vitro cultures of $\mathrm{T}$ cells from healthy individuals and from patients suffering from acute and chronic forms of ATL. As reported earlier, ${ }^{35}$ noninfected and nonstimulated $\mathrm{T}$ cells (gated as $\mathrm{CD}^{+}$cells) showed a weak expression of TfR, whereas PHA/IL-2-

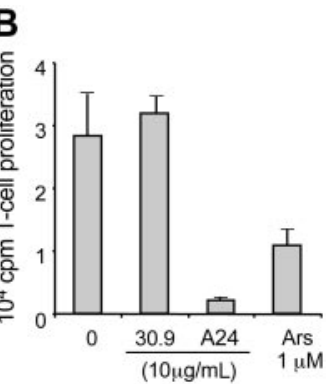

Figure 1. Activities of A24 on PBMC proliferation. (A) To investigate the activity of A24 on PBMC proliferation, cells were activated with PHA/IL-2 and incubated with different concentrations of A24 $(0-50 \mu \mathrm{g} / \mathrm{mL})$ or control antibody $30.9(0-50 \mu \mathrm{g} / \mathrm{mL})$ for 72 hours before $\left[{ }^{3} \mathrm{H}\right]$ thymidine incorporation. (B) Dendritic cell-induced allogenic T-cell proliferation was evaluated after 6 days of culture in the presence of A24, control antibody (30.9), ${ }^{9}$ or arsenic trioxide (Ars). Data represent means \pm SD of one of 3 separate experiments. activated T cells expressed high levels of TfR. HTLV-1-infected T cells from acute forms of ATL expressed TfR at levels higher than those observed in T cells from chronic ATL forms. HUT-102 and MT2 cell lines (HTLV-1-transformed cell lines) expressed TfR at lower levels than in the Jurkat T-cell line. TfR expression was correlated to the extent of T-cell activation as assessed by CD25 expression (Figure 2B). Accordingly, T cells from chronic forms of ATL expressed both CD25 and TfR at lower level than T cells from acute forms of ATL (Figure 2B). Cultures of leukemic T cells derived from ATL patients in the presence of PHA/IL-2 retained their activated phenotype (data not shown).

We then looked into the possibility of using A24 as an inhibitor of proliferation in cultures of PBMCs derived from patients with ATL. Although somewhat less efficiently than in PBMCs from healthy individuals (Figure 2C), A24 significantly blocked cell proliferation in cultures of cells from both acute and chronic forms of ATL.

HTLV-1-infected cells can proliferate in vitro, but the clones that proliferate in culture are generally not the same as those that proliferate in the patient. To verify if A24 could inhibit the emergence of HTLV-1-infected T-cell clones, we cultured cells freshly isolated from patients and from healthy individuals in the presence or absence of A24. After 2 weeks of culture, the appearance of proliferating cells was assessed by $\left[{ }^{3} \mathrm{H}\right]$-thymidine incorporation. A single dose of A24 added during the first day of culture significantly inhibited the proliferation of infected T-cell
A

Figure 2. TfR expression and antiproliferative effect of A24 on tumor cells. (A) TfR expression was examined on different cell subtypes: resting T cells (i), PHA/IL2-activated T cells (ii), lymphoma cell line (Jurkat) (iii) HTLV-1 ${ }^{+}$cell lines (HUT-102 and MT-2, respectively; iv-v), ex vivo lymphocytes of acute ATL patients (vi-vii), ex vivo lymphocytes of patients with a chronic ATL form (viii). The expression level of TfR was expressed on histograms plotting the fluorescence intensity of anti-CD71 (gray) as compared to that of the isotype control (open). Numbers in the upper right corners represent the median fluorescence intensity of the gray histograms. (B) Coexpression of TfR and CD25 on healthy and tumor cells. Resting T cells (i), PHA/IL-2-activated T cells (ii), HTLV-1 cells line (MT-2 and HUT-102, respectively; iii-iv), ex vivo lymphocytes of patients with an ATL acute form (v-vi), ex vivo lymphocytes of patients with an ATL chronic form (vii). (C) PBMCs from healthy individuals (i) and HTLV-1infected patients with an acute ATL (ii) or a chronic ATL (iii) were plated in culture wells with A24 or a contro antibody (30.9) in the presence of PHA/IL-2, for 72 hours before $\left[{ }^{3} \mathrm{H}\right]$-thymidine incorporation. (D) PBMCs from HTLV-1-infected patients with a chronic ATL form were plated in culture wells with the 30.9, A24, or Ars for 2 weeks. Emergence of HTLV-1 clones was evaluated by $\left[{ }^{3} \mathrm{H}\right]$-thymidine incorporation. Data are means $\pm \mathrm{SD}$ of one of at least 3 separate experiments with 4 acute and 3 chronic ATL patients.

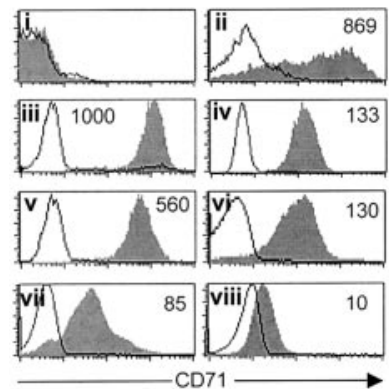

\section{C}

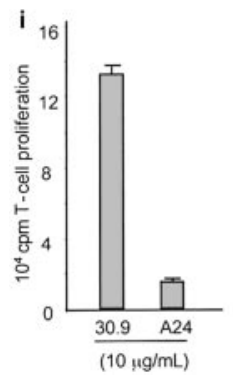

B

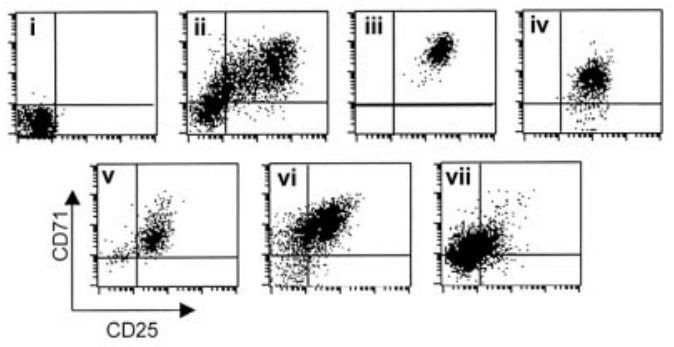

D
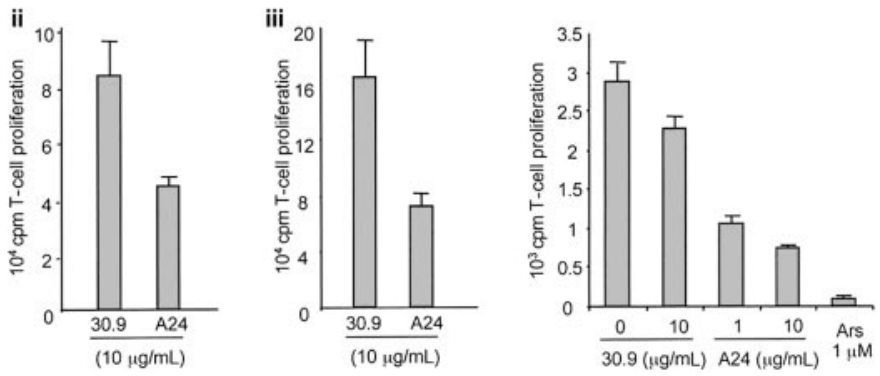
clones (Figure 2D). Control antibody 30.9 had no statistically significant effect on HTLV-1 clone proliferation. As a positive control, Ars was more efficient than A24 in blocking tumor T-cell proliferation.

\section{A24 blocks the ex vivo proliferation of cells from acute ATL forms resistant to anti-IL-2R $\alpha$ antibody}

TfR expression is essential for the proliferation of both normal and malignant T cells. Although TfR expression in normal T cells is tightly coupled to IL-2R expression, TfR expression in malignant cells is usually constitutive. It was previously shown that the anti-IL-2R $\alpha$ can efficiently block the ex vivo proliferation of cells derived from patients with chronic ATL. However, anti-IL-2R $\alpha$ was less efficient or not efficient in blocking the proliferation of cells from acute forms of ATL. ${ }^{10,12}$ Thus, we compared the abilities of A24 and anti-IL-2R $\alpha$ to block the ex vivo proliferation of HTLV-1-infected cells. Whereas anti-IL-2R $\alpha$ significantly inhibited the proliferation of cells from both healthy individuals and patients with chronic forms of ATL, it did not block the proliferation of cells derived from patients with acute ATL. In contrast, A24 significantly inhibited the proliferation of cells from patients suffering from either acute or chronic forms of ATL (Figure 3). Association of A24 and anti-IL-2R $\alpha$ in healthy individuals and acute ATL forms have no synergistic effect, whereas in chronic ATL forms the effect of combined immunotherapy in cell proliferation was less efficient than A24 treatment alone (Figure 3).

\section{Comparative effect of A24 and chemotherapies on malignant ATL cells}

We next examined the effect of the association of A24 with different chemotherapeutic agents on malignant ATL cell proliferation. Figure 4 shows that the association of chemotherapeutic agents with A24 can improve the inhibition of tumor cells' proliferation. The major inhibitory effect is observed when A24 is associated with AZT, IFN- $\alpha$, and AZT plus IFN- $\alpha$ (approximately $70 \%$ inhibition of cell proliferation).

\section{A24 competes with Fe-Tf for TfR binding}

To gain insight into the mechanism of inhibition of cell proliferation by $\mathrm{A} 24$, a series of surface plasmon resonance experiments was performed to determine the binding properties of mAb A24 and Fe-Tf to the soluble TfR1 ectodomain. A24 interacted with TfR with an equilibrium constant $\left(\mathrm{K}_{\mathrm{d}}^{\prime}\right)$ of $2.69 \mathrm{nM}$ compared with $0.983 \mathrm{nM}$ for Fe-Tf (Table 1). We then performed competition experiments to determine if the A24-binding sites on TfR overlapped with those of Fe-Tf. The saturation of TfR with A24

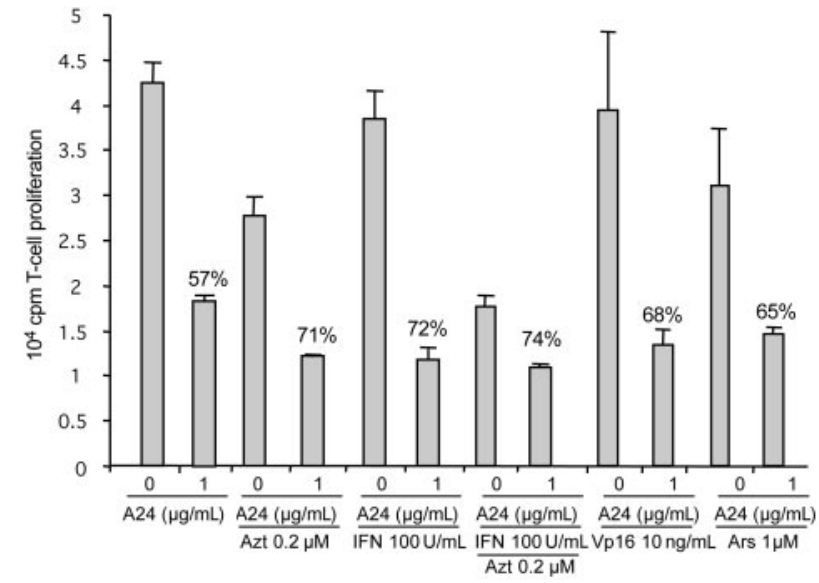

Figure 4. Comparative activities of A24, AZT, IFN- $\alpha$, VP16, and Ars on the proliferation of tumor cells. Tumor cells from a patient with chronic ATL were incubated with or without $A 24$ and treated with or without different chemotherapeutic agents such as AZT, IFN- $\alpha$, or both AZT and IFN- $\alpha$, Ars, or VP16 for 72 hours to determine the potential synergistic effect of these agents with A24. Cells were pulsed with $\left[{ }^{3} \mathrm{H}\right]$-thymidine and harvested, before measuring the incorporation of $\left[{ }^{3} \mathrm{H}\right]$ thymidine. Data are means $\pm S D$ of one representative experiment of 3 separate experiments.

partially impaired Fe-Tf binding and, reciprocally, the saturation of TfR with Fe-Tf partially prevented A24 from binding (Figure 5A-B).

The affinity of A24 for a low-density surface of TfR was 3 times lower than that of Fe-Tf. However, unlike the monovalent ligand Tf, A24 possesses 2 binding sites, and therefore the avidity of this bivalent IgG could be dependent on the available density of the receptor on the cell surface. To mimic this situation, we captured different amounts of TfR-(His) $)_{6}$ on an anti-(His) $)_{6}$ sensorchip. The dissociation rate $\left(\mathrm{k}_{\text {off }}\right)$ of the A24/ TfR complex was 6 times lower when TfR was available at higher densities. In contrast, the $\mathrm{k}_{\text {off }}$, and therefore the $\mathrm{t}_{1 / 2}$, of the Fe-Tf/TfR complex was not influenced by the density of TfR (Table 1; Figure 5C-D). This experiment suggests that A24 could preferentially bind to cells expressing high levels of TfR, that is, malignant cells.

\section{A24 inhibits the $\left[{ }^{55} \mathrm{Fe}\right]-\mathrm{Tf}$ uptake by activated T cells}

These results suggested that by interfering with Fe-Tf association with TfR, A24 could inhibit Fe-Tf uptake. To test this hypothesis, PBMCs from healthy donors were cultured in PHA/IL-2conditioned medium and were incubated with $\left[{ }^{55} \mathrm{Fe}\right]-\mathrm{Tf}$ in the presence of A24 (at $10 \mu \mathrm{g} / \mathrm{mL}$ ) or of an irrelevant isotype-matched control (antibody 30.9). As shown in Figure 6A, A24 drastically
Figure 3. Comparative activities of A24 and IL-2 $\alpha$ on cell proliferation in acute and chronic forms of ATL. Peripheral blood leukocytes from healthy individuals $(A)$, and chronic $(B)$ or acute $(C)$ forms of ATL were incubated with PHA and IL-2 for 72 hours with A24, anti-IL-2R $\alpha$, or both. Proliferation of these cells was then measured by $\left[{ }^{3} \mathrm{H}\right]$-thymidine incorporation. Data are means $\pm \mathrm{SD}$ of one of at least 3 separate experiments with 4 acute and 3 chronic ATL patients.
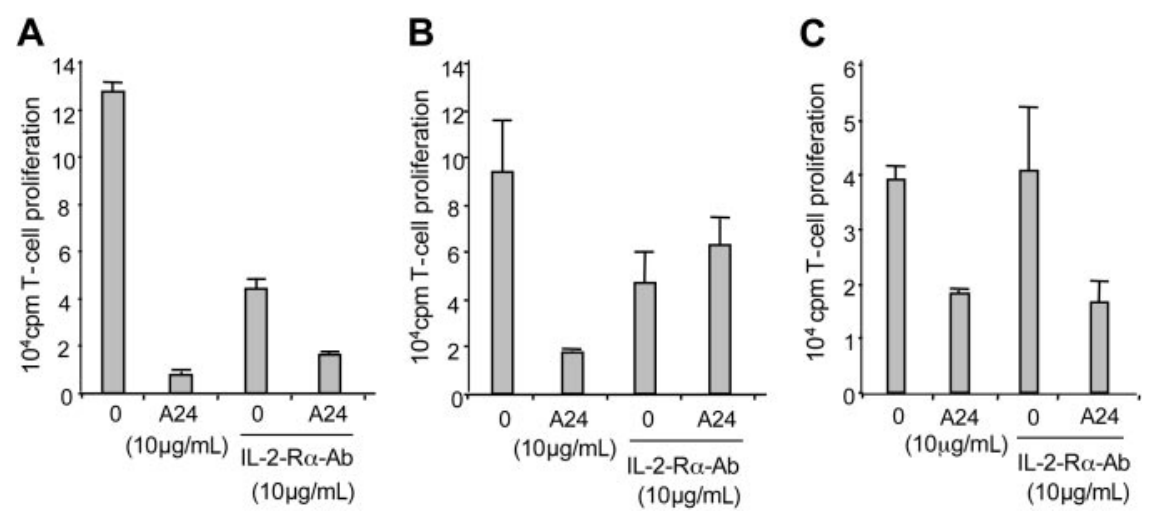
Table 1. Kinetic parameters of the interactions between immobilized TfR and soluble Tf or A24

\begin{tabular}{|c|c|c|c|}
\hline $\begin{array}{l}\text { Density of immobilized } \\
\text { receptor and ligand }\end{array}$ & $\begin{array}{c}k_{\text {on }}, 10^{5} \\
M^{-1} \times s^{-1}\end{array}$ & $\begin{array}{c}k_{\text {off }}, \\
10^{-4} \times s^{-1}\end{array}$ & $\mathbf{K}_{\mathrm{d}}^{\prime}, \mathrm{nM}^{\star}$ \\
\hline \multicolumn{4}{|l|}{ Low } \\
\hline $\mathrm{Fe}-\mathrm{Tf}$ & $12.1 \pm 1.70$ & $11.9 \pm 1.9$ & $0.98 \pm 0.21$ \\
\hline $\mathrm{mAb}$ A24 & $8.30 \pm 0.64$ & $22.3 \pm 4.8$ & $2.69 \pm 0.62$ \\
\hline \multicolumn{4}{|l|}{ High } \\
\hline $\mathrm{Fe}-\mathrm{Tf}$ & $3.04 \pm 0.63$ & $9.48 \pm 2.24$ & $3.12 \pm 0.93$ \\
\hline mAb A24 & $3.82 \pm 0.12$ & $3.88 \pm 0.91$ & $1.02 \pm 0.24$ \\
\hline
\end{tabular}

The determination of $\mathrm{k}_{\mathrm{on}}, \mathrm{k}_{\mathrm{off}}$, and $\mathrm{K}_{\mathrm{d}}^{\prime}$ from BIAcore experimental data is described in "Materials and methods." The mean value and associated SE of 3 or more independent determinations is given.

${ }^{*} K^{\prime}{ }_{d}$ is the equilibrium dissociation constant measured at the heterogeneous interface between the liquid phase and the sensorchip surface. There is no simple relationship between this constant and the $\mathrm{K}_{d}$ that would be measured in a homogeneous solution.

inhibited $\left.{ }^{55} \mathrm{Fe}\right]-\mathrm{Tf}$ uptake in PHA/IL-2-activated T cells, reaching a maximum of $80 \%$ inhibition after 2 hours of culture.

\section{A24 abrogates the recycling of TfR by HTLV-1-infected cells}

Endocytosis of transferrin via TfR is a well-established phenomenon. Diferric transferrin binds to TfR on the cell surface and is endocytosed in peripheral cytoplasmic sorting endosomes ( $\mathrm{pH}$ 6.2) and recycling endosomes ( $\mathrm{pH}$ 6.4). After iron dissociation, apotransferrin and TfR recycle back to the cell surface. It was previously shown that cross-linking of TfR by anti-TfR antibodies could induce the down-regulation of TfR expression ${ }^{36}$ in tumor cells.

To examine whether A24 could affect TfR expression at the cell surface, we cultured nonstimulated or stimulated PBMCs in the presence or absence of A24. A24 drastically down-regulated TfR at the cell surface in normal cells stimulated by PHA/IL-2 (Figure $6 \mathrm{~B})$. In addition, A24 down-regulated the expression of TfR in ex vivo cell cultures from chronic and acute forms of ATL by more than $75 \%$, and it did not interfere with CD25 expression (Figure 6B). A24 had no effect on the expression of TfR in normal nonactivated $\mathrm{T}$ cells (data not shown). Because ATL cells produce high levels of both IL-2 and IL-15, we also tested the effect of A24 on HTLV-1-infected cells from acute ATL donors cultured in IL-15 or IL-2/IL-15-conditioned medium. We observed a more than $65 \%$ down-regulation of TfR expression in both cases (data not shown).
TfR is constantly recycled in the cell with a $t_{1 / 2}$ as low as 15 minutes. To test the ability of A24 to interfere with this recycling, malignant activated $\mathrm{T}$ cells (CIB cell line, derived from a HTLV-1 patient) were treated with $\mathrm{A} 24$ at $4^{\circ} \mathrm{C}$ to block vesicular trafficking. After 30 minutes of incubation at $4^{\circ} \mathrm{C}$, cells were washed and cultured at $37^{\circ} \mathrm{C}$ for up to 180 minutes; A24 was localized by confocal microscopy. Cells that were only incubated at $4^{\circ} \mathrm{C}$ expressed the TfR complex in their membrane, as evidenced by the colocalization of A24 and WGA. After 15 minutes of culture, the presence of TfR in submembrane vesicular compartments was consistent with TfR recycling. However, after longer periods of culture, the A24-treated TfRs had not recycled to the cell surface, but instead, they had been directed to polarized intracellular compartments resembling endolysosomal vesicles. (Figure 6C).

\section{A24 induces apoptosis of activated ATL tumor cells}

Iron deprivation induces a variety of consequences, such as the reduction of cell proliferation and the activation of programmed cell death, ${ }^{37}$ a phenomenon associated with phosphatidylserine exposure and mitochondrial membrane depolarization. To determine whether A24 induced apoptosis, cells treated with A24 were assayed for the translocation of phosphatidylserine from the inner to the outer leaflet of the plasma membrane by using the annexin $\mathrm{V}$ affinity assay. Dead cells were stained by PI, which enters cells that have a disrupted plasma membrane and intercalates to DNA. Following treatment with A24, tumor cells derived from patients with acute ATL showed an increase in the number of dead cells (annexin V-PI bright) compared with cells treated with the control antibody. VP16 at $100 \mathrm{ng} / \mathrm{mL}$ was used as an apoptosis-positive control (Figure 7A). In ATL tumor T cells, a large population that stained brightly with annexin V appeared after treatment with A24 or VP16. Apoptosis induced by A24 in the TSP-derived cell line CIB (a cell model of nonacute ATL) was also analyzed. A24 induced apoptosis of the CIB cell line cultured without PHA-IL-2 (Figure 7A). As a control we included an analysis of normal and untreated PBMCs that are not proliferating and that do not undergo spontaneous apoptosis in the absence of activating factors. These cells were not sensitive to A24 (Figure 7A). DIOC was used to examine whether mitochondrial depolarization was involved in A24-dependent apoptosis. The drastic reduction in the DIOC concentration that was observed after exposure to A24 or VP16
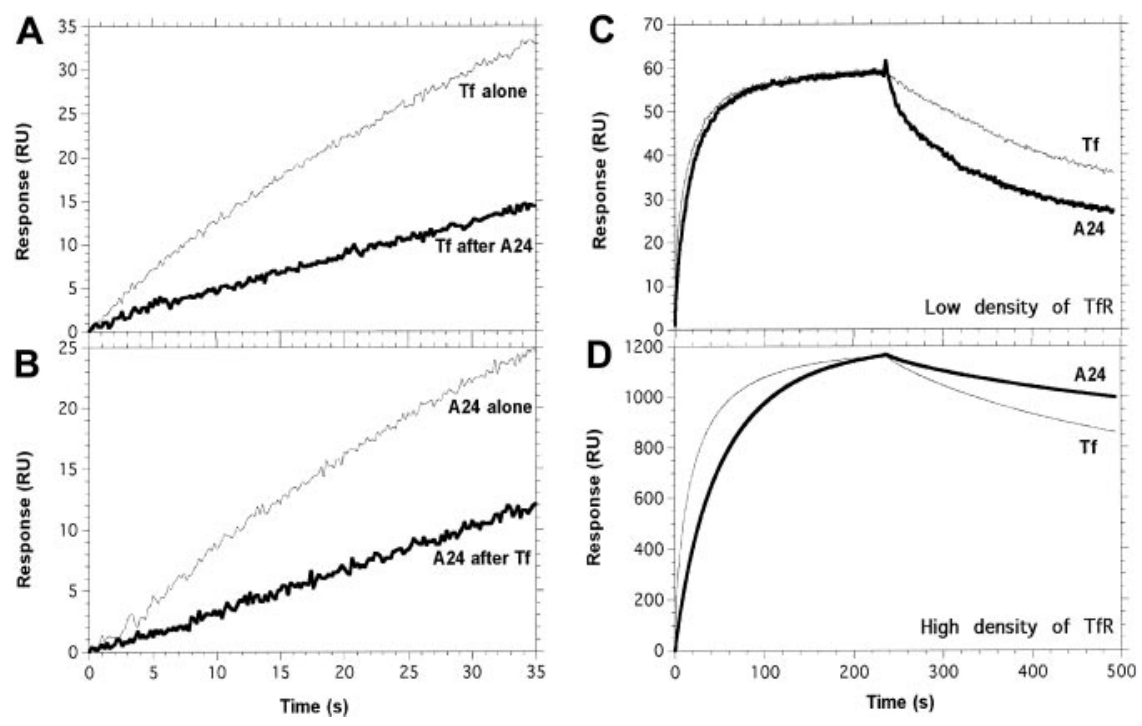

Figure 5. Tf and A24 partially compete for binding to TfR. Experimental conditions are described precisely in "Materials and methods." (A) Tf was injected across the TfR surface, after saturation with A24 (bold line) or a control buffer injection (thin line). (B) A24 was injected across the TfR surface, after saturation with Tf (bold line) or a control buffer injection (thin line). (C-D) The apparent stability of the complex between A24 and TfR is strongly dependent on the density of TfR. A series of concentrations of Fe-Tf and A24 was injected across a low-density (C, $120 \mathrm{RU})$ or a high-density (D, $1650 \mathrm{RU})$ immobilized TfR surface; only the data obtained for $134 \mathrm{nM}$ of Fe-Tf (thin line) and $62.5 \mathrm{nM}$ of A24 (bold line) are shown. A24/TfR complexes dissociate faster than Tf/TfR when TfR is present at low density $(C)$, whereas at high density, the opposite situation is observed ( $D$ and Table 1$)$. 

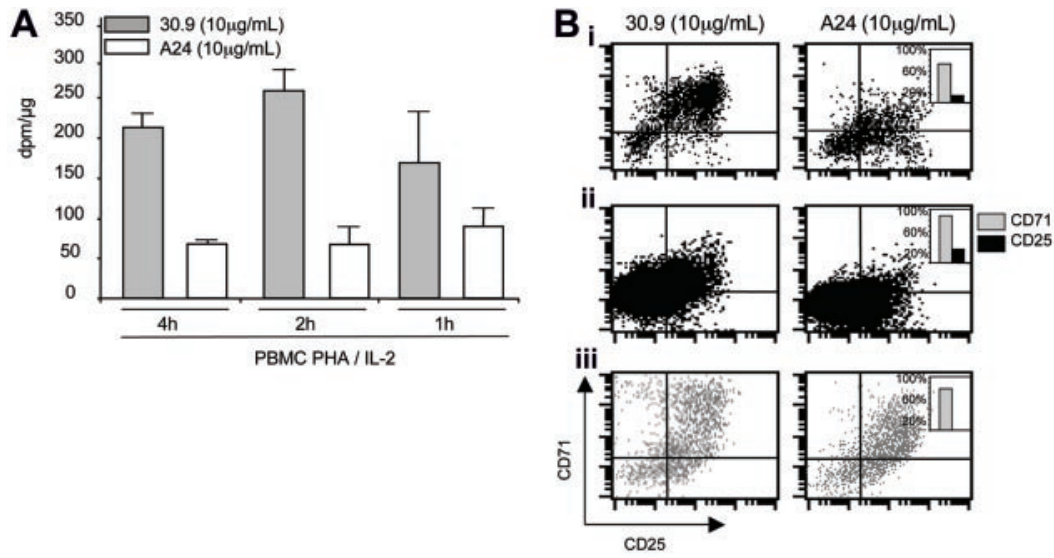

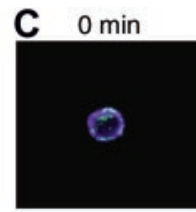

$60 \mathrm{~min}$

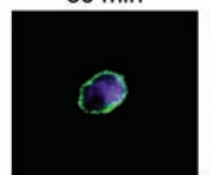

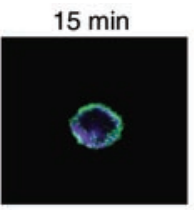

$120 \mathrm{~min}$

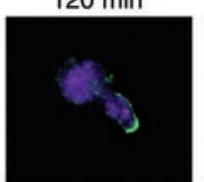

$30 \mathrm{~min}$

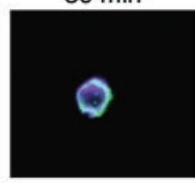

$180 \mathrm{~min}$

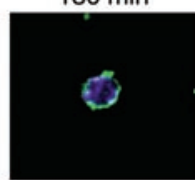

Figure 6. A24 inhibits Tf uptake and impairs TfR expression and recycling. (A) A24 inhibits Tf uptake. PBMCs were incubated with PHA and IL-2 for 24 hours before being plated in culture. To assay Tf uptake, activated cells were incubated for different time intervals with A24 ( $\square$ ) or 30.9 isotype control (娄) in the presence of $2.5 \mu \mathrm{M}$ [ $\left.{ }^{55} \mathrm{Fe}\right]-\mathrm{Tf}$. Data are means \pm SD of one experiment of 3 separate experiments. (B-C) A24 impairs TfR expression and recycling. (B) Expression of TfR and CD25 was followed on PBMCs from healthy donor (i) and patients with chronic (ii) and acute (iii) ATL. Cells were activated with PHA and IL-2 for 72 hours, in the presence of A24 or a control antibody (30.9). The inhibition percentage of the mean fluorescence intensity linked to TfR and CD25 expression is indicated in histograms located at the upper right corner of right panels. (C) CIB cells were stained at $4^{\circ} \mathrm{C}$ with $\mathrm{A} 24$ and plated under culture conditions at $37^{\circ} \mathrm{C}$ for different times ( 0 - 180 minutes) to determine the effect of A24 binding on TfR trafficking. TfR revealed with an antimouse-Cy-5 (blue) colocalized with the WGA-Alexa-488 membrane staining (green) at the initial stage (0 minutes). Colocalization disappeared progressively thereafter. Original magnification, $\times 400$.

showed that apoptosis was induced through the mitochondrial pathway (Figure 7B).

\section{Discussion}

ATL is a rapidly progressive and usually fatal malignancy of HTLV-1-infected mature $\mathrm{T}$ cells, which remains a challenge for clinicians. Until now, proposed therapies for this disease have not significantly increased the survival of patients. ${ }^{38}$ Thus, the development of alternative therapies against ATL lymphoma is essential. HTLV-1-infected $\mathrm{T}$ cells are characterized by their activated phenotype. This characteristic provides a specific rationale for anti-ATL therapies. Herein, we demonstrate that a new anti-TfR neutralizing antibody (A24) induces the apoptosis of highly proliferating ATL malignant T cells.

We have demonstrated that A24 competes with Fe-Tf for binding to TfR. This competition has 2 consequences: first, a decrease in Fe-Tf uptake, and second, a redirection of TfR to endolysosomal-like compartments, which impairs TfR recycling.
The combined result of these 2 effects is a dramatic iron deprivation for the target cells. This leads to inhibition of the cell proliferation and to apoptosis. It was recently shown that a nonblocking antirat TfR engineered with avidin (anti-TfR-Av) also triggers TfR endocytosis, inhibits cell proliferation, and induces apoptosis against myeloma cell line Y3-Ag1.2.3 and rat T-cell lymphoma cell line C58 (NT) D1.G.OVAR.1 cells, but only when aggregated. ${ }^{25}$ Interestingly, A24 did not require aggregation to induce apoptosis.

A24 is highly efficient, although its affinity for TfR is lower than that of Tf. Interestingly, we demonstrated that, in contrast to Tf, the apparent affinity (avidity) of A24 for TfR significantly increased with the density of the receptor, a consequence of the bivalency of the mAb. This could explain why A24 is more efficient against malignant $\mathrm{T}$ cells than against their normal counterparts in a physiologic environment. A24 appears to be at least 5 times more efficient than the previously described mAb 42/6 (a murine anti-human TfR $\operatorname{IgA}$ ) in inhibiting proliferation of T-cell lines. ${ }^{23}$ Importantly, the TfR epitope recognized by both antibodies does not seem to be identical. Indeed, 42/6 appears to inhibit
Figure 7. A24 induced apoptosis of HTLV-1+ cells. (A) Comparative effect of $\mathrm{A} 24,30.9$, and VP16 on the induction of programmed cell death in selected cells. Cells were activated or not with PHA and IL-2 and incubated in the presence of 30.9, A24, and VP16. Apoptotic and necrotic cells were followed by flow cytometry using an annexin V-FITC/PI kit. The percentage of cells located in right histogram quadrants is indicated: (i) cells from ATL acute form, (ii) normal, nonstimulated PBMCs, (iii) nonstimulated CIB cell line. (Bi) Annexin V staining of activated leukocytes from patients with acute ATL; cells were incubated with 30.9 (grey line), VP16 (discontinuous line), or A24 (continuous line). (Bii) Mitochondrial depolarization revealed by DIOC staining of activated leukocytes from ATL acute patient incubated with 30.9 (grey line), VP16 (discontinuous line), or A24 (continuous line). Data represent one of 3 different experiments.
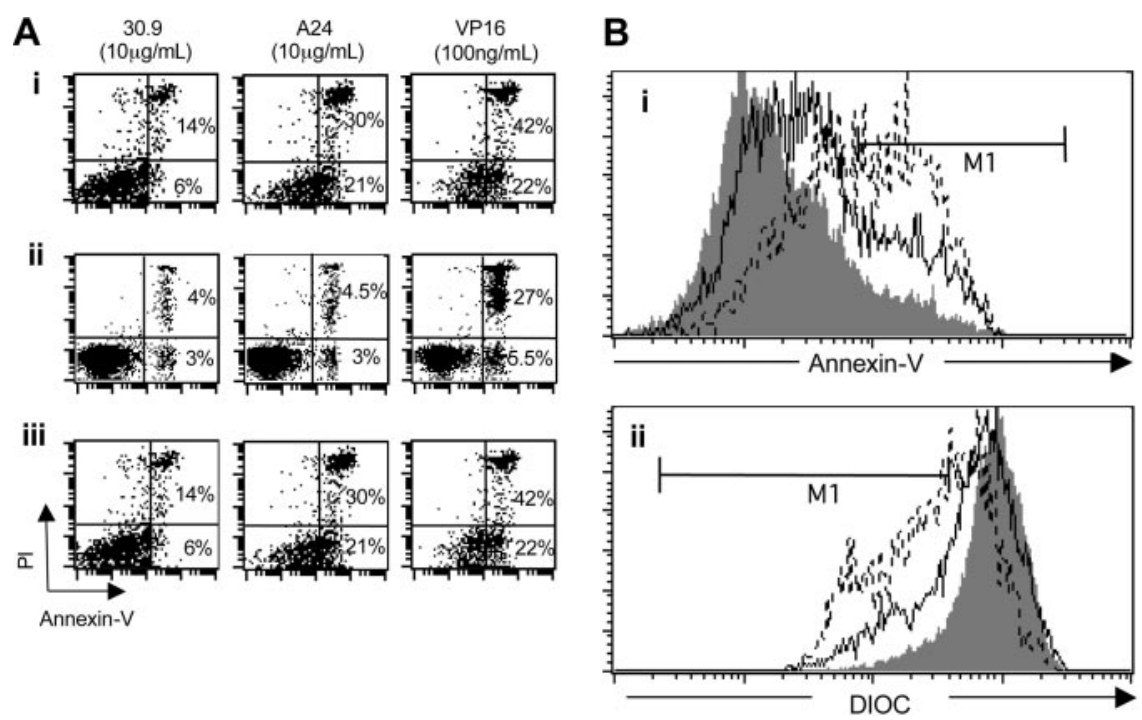
Tf binding to TfR by a noncompetitive mechanism. ${ }^{39}$ In contrast, our surface plasmon resonance results demonstrate that A24 prevents $\mathrm{Tf}$ from binding to TfR in a competitive manner, suggesting that A24 and Tf bind to the same, or overlapping, sites. Physiologic consequences of the interaction of A24 and $42 / 6$ with the target cell are also different. Although 42/6 has a profound effect on the $\mathrm{S}$ phase of the cell cycle, ${ }^{23,40} \mathrm{~A} 24$ acts by inducing the apoptosis of target cells.

These results suggest that A24 could be efficient in killing tumor cells by itself. Hege et al have shown that anti-TfR antibodies can be used to target liposomes specifically to ATL malignant cell lines MT-1 and HUT-102. The authors studied the capacity of the liposome-conjugated antibodies for specific binding, internalization, and intracellular drug delivery. ${ }^{41}$ Interestingly, drug-containing anti-TfR liposomes were 40 to 60 times more effective in inhibiting the growth of the ATL cell lines than anti-IL-2R $\alpha$ liposomes. ${ }^{41}$ However, no study was performed against ex vivo ATL T cells. Because these cells are efficiently targeted by A24, we envisage trying to determine whether this antibody is able to deliver antitumor drugs when coupled to liposomes.

The establishment of an in vivo model of ATL using NOD/SCID mice provided a fundamental step for the evaluation of new ATL immunotherapies. ${ }^{42,43}$ Anti-CD2 and anti-IL-2R $\alpha$ immunotherapies have been evaluated using this model and shown to be efficient in controlling tumor progression in the human xenografted mice. The in vivo antitumor activity of anti-CD2 antibodies relies mainly on antibodydependent cytotoxicity (ADCC). ${ }^{43}$ TfR expression is up-regulated in HTLV-1-infected T cells derived from both acute and chronic ATL forms. These cells should therefore be efficiently targeted by A24 in the in vivo ATL model. In addition, in contrast to anti-CD2 antibodies that do not kill tumor cells efficiently, A24 has an intrinsic inhibitory effect on tumor proliferation. Thus, in immunotherapies using ATL xenograft models, A24 could act both by its intrinsic capacity and ADCC. Because this latter mechanism may be impaired in the immunocompromised ATL patients, A24 could be more efficient than anti-CD2 antibodies for the treatment of human ATL.

Treatment of HTLV-1-associated myelopathy/tropical spastic paraparesis (HAM/TSP) with anti-IL-2R $\alpha$ antibodies reduces both the viral load and neurologic features of the disease. ${ }^{44}$ In addition, immuno- therapy of ATL patients with anti-IL-2R $\alpha$ antibodies led to a partial or complete remission in 6 of 19 patients with ATL. ${ }^{10}$ The anti-IL-2R $\alpha$ antibodies act by neutralizing the stimulatory effect of IL-2 on its receptor. However, although they express high levels of surface CD25 receptors, tumor cells derived from patients with late-phase acute ATL do not express IL-2 and are resistant to anti-IL-2R $\alpha$ immunotherapy. This IL-2-independent highly proliferative phase is believed to be associated to an IL-15 autocrine loop. ${ }^{12}$

Aggressive forms of ATL are often accompanied by an important tumoral syndrome characterized by massive lymphadenopathy, hepatosplenomegaly, lytic bone lesions, multiple visceral lesions, and skin and lung infiltration. Acute ATL forms have a poor prognosis with a median survival of 6 months.

Here, we have shown that A24 can specifically bind highly proliferating T cells, inhibit cell proliferation, and induce apoptosis even in anti-IL-2R $\alpha$-resistant acute and lymphoma ATL. These results argue in favor of a new immunotherapy based on A24 for the treatment of highly proliferating acute ATL. Importantly, the innocuous aspect of anti-TfR antibodies has been previously shown. During a phase 1a trial, mAb 42/6 was well tolerated and antibody concentrations that were capable of inhibiting malignant blood cell growth in vitro were not toxic in the serum. ${ }^{45}$ Moreover, we show here that A24 does not induce apoptosis of nonproliferating normal PBMCs, providing additional evidence for the potential harmlessness of A24 treatment.

We also showed that the association of A24 with ATL chemotherapies including VP16, or the combination of both AZT and IFN- $\alpha$, led to significantly synergistic effects. Furthermore, by blocking the emergence of tumor clones, A24 could also be used as a therapy to prevent the transformation of chronic ATL disease into an aggressive form, or to reduce the viral load in inflammatory disorders associated with HTLV-1 infection, including HAM/TSP, polymyositis, and arthritis.

Taken together, our results suggest that A24 immunotherapy may represent a novel and efficient tool in the treatment of HTLV-1-related diseases.

\section{Acknowledgment}

We thank Pamela J Bjorkman for providing us with the lytic baculovirus/insect cell recombinant soluble version of human TfR.

\section{References}

1. Hinuma $\mathrm{Y}, \mathrm{Komoda} \mathrm{H}$, Chosa T, et al. Antibodies to adult T-cell leukemia-virus-associated antigen (ATLA) in sera from patients with ATL and controls in Japan: a nation-wide sero-epidemiologic study. Int J Cancer. 1982;29:631-635.

2. Takatsuki K, Hinuma Y. Adult T-cell leukemia/lym phoma. In: Gallo RC, Wong-Staal F, eds. Retrov rus Biology and Human Disease. New York, NY: Dekker; 1990:147.

3. Bunn PA Jr, Schechter GP, Jaffe E, et al. Clinical course of retrovirus-associated adult T-cell lymphoma in the United States. N Engl J Med. 1983 309:257-264.

4. Gill PS, Harrington W Jr, Kaplan MH, et al. Treatment of adult T-cell leukemia-lymphoma with a combination of interferon alfa and zidovudine. N Engl J Med. 1995;332:1744-1748.

5. Hermine O, Bouscary D, Gessain A, et al. Brie report: treatment of adult T-cell leukemia-lymphoma with zidovudine and interferon alfa. N Engl J Med. 1995;332:1749-1751.

6. Hermine O, Allard I, Levy V, Arnulf B, Gessain A, Bazarbachi A. A prospective phase II clinical trial with the use of zidovudine and interferon-alpha in the acute and lymphoma forms of adult T-cell leukemia/lymphoma. Hematol J. 2002;3:276-282.
7. Bazarbachi A, Hermine O. Treatment with a com bination of zidovudine and alpha-interferon in naive and pretreated adult T-cell leukemia/lymphoma patients. J Acquir Immune Defic Syndr Hum Retrovirol. 1996;13(suppl 1):S186-190.

8. Greene WC, Robb RJ. Receptors for T-cell growth factor: structure, function and expression on normal and neoplastic cells. Contemp Top Mol Immunol. 1985;10:1-34.

9. Markham PD, Salahuddin SZ, Gallo RC. In vitro cultivation of normal and neoplastic human T lymphocytes. Clin Haematol. 1984;13:423-446.

10. Waldmann TA, White JD, Goldman CK, et al. The interleukin-2 receptor: a target for monoclonal antibody treatment of human T-cell lymphotrophic virus I-induced adult T-cell leukemia. Blood. 1993;82:1701-1712

11. Waldmann TA, White JD, Carrasquillo JA, et al. Radioimmunotherapy of interleukin-2R alphaexpressing adult T-cell leukemia with Yttrium-90labeled anti-Tac. Blood. 1995;86:4063-4075

12. Waldmann TA. The IL-2/IL-15 receptor systems: targets for immunotherapy. J Clin Immunol. 2002; 22:51-56.

13. Petrini M, Pelosi-Testa E, Sposi NM, et al. Consti- tutive expression and abnormal glycosylation of transferrin receptor in acute T-cell leukemia. Cancer Res. 1989;49:6989-6996.

14. Trowbridge IS, Shackelford DA. Structure and function of transferrin receptors and their relationship to cell growth. Biochem Soc Symp. 1986;51: 117-129.

15. Schneider YJ, Limet JN, Octave JN, Otte-Slachmuylder C, Crichton RR, Trouet A. The role of receptor-mediated endocytosis in iron metabolism. Prog Clin Biol Res. 1982;91:495-521.

16. Klausner RD, Ashwell G, van Renswoude J, Harford JB, Bridges KR. Binding of apotransferrin to K562 cells: explanation of the transferrin cycle. Proc Natl Acad Sci U S A. 1983;80:2263-2266.

17. van Renswoude J, Bridges KR, Harford JB, Klausner RD. Receptor-mediated endocytosis of transferrin and the uptake of fe in K562 cells: identification of a nonlysosomal acidic compartment. Proc Natl Acad Sci U S A. 1982;79:61866190.

18. Taetle R, Honeysett JM. Gamma-interferon modulates human monocyte/macrophage transferrin receptor expression. Blood. 1988;71:1590 1595. 
19. Lesley J, Hyman R, Schulte R, Trotter J. Expression of transferrin receptor on murine hematopoietic progenitors. Cell Immunol. 1984;83:14-25.

20. Gatter KC, Brown G, Trowbridge IS, Woolston RE, Mason DY. Transferrin receptors in human tissues: their distribution and possible clinical relevance. J Clin Pathol. 1983;36:539-545.

21. Faulk WP, Hsi BL, Stevens PJ. Transferrin and transferrin receptors in carcinoma of the breast. Lancet. 1980;2:390-392.

22. Shindelman JE, Ortmeyer AE, Sussman HH Demonstration of the transferrin receptor in human breast cancer tissue. Potential marker for identifying dividing cells. Int J Cancer. 1981;27: 329-334.

23. Trowbridge IS, Lopez F. Monoclonal antibody to transferrin receptor blocks transferrin binding and inhibits human tumor cell growth in vitro. Proc Natl Acad Sci U S A. 1982;79:1175-1179.

24. Taetle R, Honeysett JM, Trowbridge I. Effects of anti-transferrin receptor antibodies on growth of normal and malignant myeloid cells. Int J Cancer. 1983:32:343-349.

25. Ng PP, Dela Cruz JS, Sorour DN, et al. An antitransferrin receptor-avidin fusion protein exhibits both strong proapoptotic activity and the ability to deliver various molecules into cancer cells. Proc Natl Acad Sci U S A. 2002;99:10706-10711.

26. Moura IC, Centelles MN, Arcos-Fajardo M, et al. Identification of the transferrin receptor as a nove immunoglobulin ( $\mathrm{lg}) \mathrm{A} 1$ receptor and its enhanced expression on mesangial cells in IgA nephropathy. J Exp Med. 2001;194:417-425.

27. Pastorelli C, Veiga J, Charles N, et al. Phospholipid scramblase, a new effector of Fc varepsilon RI signaling in mast cells. Mol Immunol. 2002;38: 1235

28. Bazarbachi A, El-Sabban ME, Nasr R, et al. Arsenic trioxide and interferon-alpha synergize to induce cell cycle arrest and apoptosis in human T-cell lymphotropic virus type I-transformed cells. Blood. 1999;93:278-283.

29. Shirono K, Hattori T, Takatsuki K. A new classification of clinical stages of adult T-cell leukemia based on prognosis of the disease. Leukemia. 1994;8:1834-1837.

30. Tordjman R, Lepelletier Y, Lemarchandel V, et al A neuronal receptor, neuropilin-1, is essential for the initiation of the primary immune response. Nat Immunol. 2002;3:477-482.

31. Zermati Y, Garrido C, Amsellem S, et al. Caspase activation is required for terminal erythroid differentiation. J Exp Med. 2001;193:247-254.

32. Kotamraju S, Chitambar CR, Kalivendi SV, Joseph J, Kalyanaraman B. Transferrin receptordependent iron uptake is responsible for doxorubicin-mediated apoptosis in endothelial cells: role of oxidant-induced iron signaling in apoptosis. J Biol Chem. 2002;277:17179-17187.

33. Lebron JA, Bennett MJ, Vaughn DE, et al. Crystal structure of the hemochromatosis protein HFE and characterization of its interaction with transferrin receptor. Cell. 1998;93:111-123.

34. Vidal C, Matsushita S, Colamonici OR, Trepel JB, Mitsuya H, Neckers LM. Human T lymphotropic virus I infection deregulates surface expression of the transferrin receptor. J Immunol. 1988;141: 984-988.

35. Neckers LM. Regulation of transferrin receptor expression and control of cell growth. Pathobiology. 1991;59:11-18.

36. Lesley J, Schulte R, Woods J. Modulation of transferrin receptor expression and function by anti-transferrin receptor antibodies and antibody fragments. Exp Cell Res. 1989;182:215-233.

37. Haq RU, Wereley JP, Chitambar CR. Induction of apoptosis by iron deprivation in human leukemic
CCRF-CEM cells. Exp Hematol. 1995;23:428 432.

38. Shimoyama M. Diagnostic criteria and classification of clinical subtypes of adult T-cell leukaemialymphoma. A report from the Lymphoma Study Group (1984-87). Br J Haematol. 1991;79:428437.

39. Taetle R, Castagnola J, Mendelsohn J. Mechanisms of growth inhibition by anti-transferrin receptor monoclonal antibodies. Cancer Res. 1986; 46:1759-1763.

40. Mendelsohn J, Trowbridge I, Castagnola J. Inhibition of human lymphocyte proliferation by monoclonal antibody to transferrin receptor. Blood. 1983;62:821-826.

41. Hege KM, Daleke DL, Waldmann TA, Matthay KK. Comparison of anti-Tac and anti-transferrin receptor-conjugated liposomes for specific drug delivery to adult T-cell leukemia. Blood. 1989;74 2043-2052.

42. Phillips KE, Herring B, Wilson LA, et al.. IL-2Ralpha-directed monoclonal antibodies provide effective therapy in a murine model of adult T-cell leukemia by a mechanism other than blockade of IL-2/IL-2Ralpha interaction. Cancer Res. 2000; 60:6977-6984.

43. Zhang Z, Zhang M, Ravetch JV, Goldman C Waldmann TA. Effective therapy for a murine model of adult T-cell leukemia with the humanized anti-CD2 monoclonal antibody, MEDI-507. Blood. 2003;102:284-288.

44. Lehky TJ, Levin MC, Kubota R, et al. Reduction in HTLV-I proviral load and spontaneous lymphoproliferation in HTLV-I-associated myelopathy/tropical spastic paraparesis patients treated with humanized anti-Tac. Ann Neurol. 1998;44:942-947.

45. Brooks D, Taylor C, Dos Santos B, et al. Phase la trial of murine immunoglobulin A antitransferrin receptor antibody 42/6. Clin Cancer Res. 1995;1: 1259-1265. 